\title{
PERSPECTIVE ASPECTS OF OPTIMIZING RECREATIONAL NATURE MANAGEMENT WITHIN PRYUDAYSKYY AQUATIC-TERRAIN RECREATIONAL COMPLEX
}

\author{
${ }^{1}$ Maryna KULINICH, ${ }^{2}$ Nataliya TRON \\ 'Taras Shevchenko National University of Kyiv, Ukraine \\ ${ }^{2}$ Berezovorudskyy College of Poltava State Agrarian Academy, Ukraine \\ 'mai1989@ukr.net
}

\begin{abstract}
The article presents the basic aspects of the impact of recreational activities on the environment. Also, there was investigated the state of existing elements of organized recreation within Pryudayskyy aquatic-terrain recreational complex (ATRC) and was found objectively existing problems of recreation within it. This work in its basis based on several concepts, including the concept of functional zoning of recreational territories and the concept of recreational modules. Combining the fundamental positions of this two concepts, and, also, taking into account the state building codes of Ukraine about arranging of outdoor recreation - all of this allowed to propose concrete steps to optimize the functional organization of recreation within Pryudayskyy aquatic-terrain recreational complex. These steps are presented as a description of the proposed scheme of functional organization of recreation within the Pryudayskyy ATRC. In the developed scheme, there was presented individual recreational modules with different specialization and point elements of recreational improvement of the coastal area and aquatic area of Uday River at the site between villages Velyka Krucha and Deymanivka.
\end{abstract}

Key words: Pryudayskyy ATRC, recreational nature management, recreational module, functional zoning, state building codes of Ukraine.

DOI: https://doi.org/10.17721/2413-7154/2016.76.62-66

UDC: $379.84(477.53)$

\section{ПЕРСПЕКТИВНІ АСПЕКТИ ОПТИМІЗАЦІЇ РЕКРЕАЦІЙНОГО ПРИРОДОКОРИСТУВАННЯ В МЕЖАХ ПРИУДАЙСЬКОГО АКВАЛЬНО-ТЕРАЛЬНОГО РЕКРЕАЦІЙНОГО КОМПЛЕКСУ}

\author{
'Марина КУЛІНІЧ, ${ }^{2}$ Наталія ТРОНЬ \\ 'Київський начіональний університет імені Тараса Шевченка, Україна \\ ${ }^{2}$ Березоворудський технікум Полтавської державної аграрної академії, Україна \\ 'mai1989@ukr.net
}

\begin{abstract}
Резюме: В статті представлено основні аспекти впливу рекреаційної діяльності на природне середовище, досліджено стан наявних елементів організованої рекреації в межах Приудайського аквально-террального рекреаційного комплексу та виявлено об'єктивно існуючі проблеми організації рекреації в його межах. Дана робота в своїй основі опирається на декілька концепцій, серед яких концепція функціонального зонування рекреаційних територій та концепція рекреаційних модулів. Поєднання фундаментальних позицій цих двох концепцій, а також врахування державних будівельних норм України по облаштуванню місць відпочинку на природі, дозволили запропонувати конкретні прикладні кроки по оптимізації функціональної організації рекреації в межах Приудайського аквально-террального рекреаційного комплексу. Ці кроки представлені у вигляді опису до запропонованої схеми функціональної організації рекреації Приудайського АТРК. На розробленій схемі представлено як окремі рекреаційні модулі з різною спеціалізацією, так і точкові елементи рекреаційного облаштування прибережної території і акваторії річки Удай на ділянці від с. Велика Круча до с. Дейманівка..
\end{abstract}

Ключові слова: Приудайський АТРК, рекреаційне природокористування, рекреаційний модуль, функціональне зонування, державні будівельні норми України.

DOI: https://doi.org/10.17721/2413-7154/2016.76.62-66

УДК: $379.84(477.53)$

Вступ. Аквально-терральні рекреаційні комплекси - це одні 3 найулюбленіших місць відпочинку населення в теплу пору року. Однак, оскільки документальне оформлення місця пляжного відпочинку в Україні є занадто затратною процедурою як за часом, так i за коштами, більшість рекреаційних занять в межах аквальнотерральних рекреаційних комплексів проводяться неорганізовано i незбалансовано, а це значить,

(C) М. Кулініч, Н. Тронь

що рекреанти, задовольняючи свої рекреаційні потреби, здійснюють різноманітні, переважно деструктивні, впливи на довкілля. Останнє зумовлює необхідність вивчення особливостей рекреаційного природокористування в межах поверхневих водних об'єктів та їх прибережних територій (аквальнотерральних комплексів) та розробки пропозицій $\mathrm{i}$ заходів щодо вирішення численних конфліктних ситуацій, що виникають в наслідок незбалансованої та неорганізованої рекреації. Адже саме аквальнотерральні рекреаційні комплекси часто стають 
місцем конфлікту інтересів водокористувачів 3 господарською ціллю і ціллю відпочинку, i, навіть, між самими відпочивальниками (плавці - рибалки любителі прогулятись на човні). Найбільш адекватним способом вирішення цих проблем є розробка схем функціонального зонування аквальнотерральних рекреаційних комплексів 3 метою збалансування рекреаційного природокористування в їх межах.

Аналіз останніх досліджень і публікацій. Дослідженням функціональної організації місць відпочинку займався російський дослідник О. В. Новіков (2012), який адаптував розроблену американськими архітекторами концепцію точкових рекреаційних модулів до широких потреб рекреаційної географії. Особливості організації рекреації в межах поверхневих водних об'єктів були предметом вивчення Ю.С.Васильєва (1983). Плануванням місць відпочинку на природі займались австралійські дослідники S. Bell (2005) та T. C. Brown (2003), які розробили і запропонували чіткі рекомендації по облаштуванню різних варіантів місць відпочинку на природі від оглядових майданчиків, ігрових дитячих майданчиків, місць для пікніків, кемпінгів, до повнофункціональних санвузлів, автомобільних паркінгів тощо. Чіткі i грунтовні норми і рекомендації щодо планування територій під місця відпочинку масового відвідування розроблені і представлені в державних будівельних нормах України. Зауважимо, що норм, пропозицій і рекомендацій по облаштуванню місць відпочинку на природі є дуже багато, проте в Україні ці норми практично не реалізуються на практиці.

Тому, мета даної роботи полягає у розробці прикладних схем оптимізації функціональної організації рекреації в межах поверхневих водних об'єктів та їх прибережних територій на прикладі Приудайського аквально-террального рекреаційного комплексу.

Виклад основного матеріалу. Обгрунтування раціональної організації рекреації базується на виявленні і оцінці конкретних ділянок простору встановленні їх якісних властивостей і розрахунок необхідних площ природних комплексів, що виступають як ресурси відпочинку. Міжеселенські території, разом з їх різноманітним рельєфом, лісами, луками, полями, ріками, озерами, фауною і чистим повітрям складають «основні фонди» організації рекреації на природі, в той час як технічні засоби облаштування простору являються «супутніми фондами» організації рекреації на природі.

Відповідність між видами рекреаційних занять і ландшафтом грунтується на понятті про функціональні якості ландшафтів. Воно полягає в тому, що кожен ландшафт володіє певними умовами і ресурсами, що можуть бути використані найбільш повно лише для організації конкретних видів рекреаційних занять. Кожному виду рекреаційних занять притаманні свої особливості:

- характер дій відпочиваючих (рухливість, спокій і розміреність);

- інтенсивність використання території;



Рис. 1. Схема функціональної організації Приудайського АТРК 
- специфічні особливості облаштування простору тощо.

Наразі типовою є ситуація, коли в більшості випадків реалізації неорганізованої рекреації люди залишають «на ландшафті» відбитки своєї присутності: витоптані стежки та локалізовані місця відпочинку, сміття, кострища, пошкоджена флора та стурбована фауна. Для того, щоб допомогти природі впоратися із тиском на неї рекреантів, a також залишити сьогоднішній рекреаційний ландшафт привабливим ще й для майбутніх відвідувачів, ми мусимо звертатись до прийомів функціональної організації місць рекреації.

Функціонально-організаційне зонування - це спосіб раціональної організації і використання простору, що полягає у виділенні окремих зон призначених для особливих видів діяльності людини. Функціонально-організаційне зонування в межах конкретного ландшафтно-рекреаційного комплексу тісно ув'язане 3 видами рекреаційних занять.

Окремі види рекреаційних занять зазвичай об'єднують для створення рекреаційних модулів. Під рекреаційними модулями О.В.Новіков [5] пропонує розглядати набір елементарних рекреаційних занять, об'єднаних єдиною ціллю та прив'язаних до конкретної території. Виходячи 3 цього, функціональні зони в межах конкретного АТРК можна розглядати як окремі рекреаційних модулі зі своєю унікальною специфікою.

Проектування простору аквально-террального рекреаційного комплексу має здійснюватися поетапно з поступовою фіксацією і виокремленням в просторі функціонально-організаційних зон окремих рекреаційних модулів.

Виділення різних функціонально-організаційних рекреаційних зон в межах аквально-террального рекреаційного комплексу $\epsilon$ складним завданням планування раціонального природокористування, що вимагає врахування інтересів всіх потенційних рекреантів. На даний час до вирішення питання функціонально-організаційного зонування рекреаційних територій немає єдиного підходу. Величезна різноманітність природних комплексів в різних кліматичних районах, різноманіття видів рекреації не дозволяють виконувати зонування територій за жорсткою схемою.

Зонування АТРК для конкретних видів відпочинку здійснюється в залежності від гідрологічних, санітарно-гігієнічних, ландшафтних умов. Необхідність зазначеного різновиду зонування АТРК обумовлена різноманіттям видів рекреації і відмінностями в характері їх реалізації. Багато видів відпочинку несумісні навіть в період короткочасного використання території. Так, Ю. С. Васильєв [7] акцентує увагу на тому, що рибна ловля неможлива в районі пляжів і на ділянках, які використовуються для водного спорту; в місцях масового купання неприпустимо катання на гребних човнах i тим більше на моторних човнах тощо.

Врахування санітарно-гігієнічних умов при функціональному зонуванні АТРК необхідне у зв'язку з тим, що різні види відпочинку по-різному залежать від санітарного стану водного об'єкту. Так, зонування акваторії водойм для купання, заняття водними лижами, аматорського рибальства необхідно проводити строго відповідно до санітарногігієнічних вимог; у свою чергу види відпочинку, які використовують плавзасоби, менш вимогливі до санітарно-гігієнічних умов водойми [7].

При зонуванні АТРК для окремих видів відпочинку необхідно враховувати чинники психологічної комфортності, уникати нераціонального поєднання в межах однієї території декількох рекреаційних модулів 3 різними вимогами до режиму відпочинку.

АТРК зазвичай інтенсивно відвідуються у вихідні дні 3 метою проведення короткочасного відпочинку. Бажано, щоб ці комплекси були спеціально облаштованими і об'єднували в собі обладнаний пляж, об'єкти громадського харчування та культурно-масового обслуговування, човнові станції, стоянки для автомашин тощо. При облаштуванні таких АТРК однією 3 основних проблем $\epsilon$ визначення співвідношення, в якому поєднуватимуться різні функціональні зони АТРК.

На акваторії виділяються окремі зони для купання, катання на гребних човнах, катання на водних лижах, аматорського рибальства тощо. Зони обгороджуються попереджувальними буйками. Зонування рекреаційних акваторій повинне здійснюватися 3 урахуванням співвідношення розмірів водойми i ділянок, необхідних для організації окремих видів відпочинку. Для руху маломірного флоту іноді виділяють спеціальні траси, що проходять далеко від берега, зон купання, місць нересту тощо.

Відповідно до державних будівельних норм України [3, 4] пляжна і припляжна зони обов'язково мають включати наступні елементи благоустрою: тверді види покриття проїзду, комбіновані види покриття доріжок, озеленення, питні фонтанчики, лави, урни, контейнери для збирання побутових відходів, обладнання пляжу (навіси від сонця, лежаки, кабінки для переодягання тощо), обладнання для паркування велосипедів, зони тихого відпочинку 3 ділянками зелених насаджень і навісами для тіні; спортивні зони 3 дитячими ігровими майданчиками. Розміри території пляжів, які розміщуються у зонах короткочасного відпочинку, слід приймати не менше 8 м $^{2}$ на одного відвідувача. Крім того, довжину берегової смуги річкових i озерних пляжів слід приймати не менше 0,25 м на одного відвідувача. Урни необхідно розташовувати не менше ніж за 10 м від урізу води. Урни мають бути розставлені 3 розрахунку не менше однієї урни на 625 м $^{2}$ території пляжу. Інформаційні щити і покажчики треба розміщувати біля входів на пляж. Ширина прогулянкових доріжок повинна бути кратною 0,75 - ширина смуги руху однієї людини. Рятувальні станції і медпункти розміщуються у межах пляжної зони на підвищених ділянках, що забезпечують достатню видимість 3 будь-якої точки пляжу. Медпункт краще за все позначати всім звичним 
знаком - червоним хрестом на білому тлі. На території пляжу мають бути встановлені питні фонтанчики. Відстань між місцями розташування таких фонтанчиків не повинна перевищувати 70м. Пішохідні доріжки, усі об'єкти та споруди (кабіни для переодягання, туалетні та душові приміщення, адміністративні приміщення тощо) в межах рекреаційного комплексу треба проектувати 3 урахуванням потреб маломобільних груп населення. Розміри стоянок автомобілів біля АТРК на 100 одночасних відвідувачів має становити 15-20 машино-місць [3, 4].

Території для організації відпочинку населення виділяються в межах АТРК, найбільш сприятливих за гідрологічними, ландшафтними i санітарногігієнічними умовами, в мальовничій місцевості, серед великих зелених масивів, де існують мінімальні можливості до виникнення шуму та забруднення повітря, води і грунту.

В даній роботі зосереджено увагу на прикладі Приудайського АТРК, як представника аквальнотерральних комплексів лівих приток р. Дніпро 3 їх широкими долинами. Приудайський АТРК знаходиться в межах національного природного парку «Пирятинський» та його околиць уздовж течії р. Удай на ділянці між с. Велика Круча та с. Дейманівка. Протяжність Приудайського АТРК становить понад 9км.

Польові спостереження в межах Приудайського АТРК, атакождані, отриманівідНПП«Пирятинський» [8], показали, що в межах досліджуваного АТРК активно організовується рекреаційна діяльність та наявні обладнані зони регульованої рекреації у вигляді місць для короткострокового відпочинку - альтанки, навіси від дощу, столи, мангали, волейбольні майданчики, містки до річки, санітарні зони.

В межах Приудайського АТРК здійснюється пішохідний туризм. За підтримки НПП «Пирятинський» розроблені i функціонують екологічні стежки по території парку. Одна 3 таких стежок - «Природні та культурні пам'ятки Пирятинщини» - проходить в межах досліджуваного АТРК по правобережжю р. Удай на ділянці від с. Велика Круча до с. Повстин. Крім того, в межах Приудайського АТРК організовуються сплави по р. Удай. Оскільки р. Удай та їі заплава в межах досліджуваного АТРК належать до природоохоронних територій, рекреаційна діяльність там може здійснюватись лише в рамках «Положення про рекреаційну діяльність в межах територій та об'єктів природно-заповідного фонду України» [6]. Тобто, рекреаційні заняття в межах Приудайського АТРК, що пов'язані безпосередньо 3 p. Удай та їі заплавою, мають бути строго орієнтовані на охорону природи та еколого-освітню рекреацію. Крім сплавів, тут організовується аматорський збір грибів та ягід, риболовля, купання.

Декілька років тому русло річки на ділянці простягання безпосередньо Приудайського АТРК розчистили і поглибили, а в суцільних заростях очерету прорубали коридори і рукави для полегшення організації сплавів по річці. Складніша ситуація 3 пляжним відпочинком. Враховуючи те, що лівий берег річки Удай в межах досліджуваного АТРК є крутим, а на правому - підходи до води часто порослі очеретом, то пляжі тут не облаштовані. Їх взагалі як таких і немає, а підхід у воду для купання забезпечують високі i довгі містки від берега через зарослі очерету до розчищеного русла річки, придатного для купання.

На рисунку 1 представлено схему функціональної організації Приудайського АТРК. На схемі представлено як уже існуючі елементи рекреаційного облаштування Приудайського АТРК, так і перспективні пропозиції у вигляді рекреаційних модулів. В межах Приудайського АТРК нами було виділено 2 рекреаційні модулі.

Рекреаційний модуль 1 спеціалізується на екскурсійно-пізнавальній пішохідній рекреації та пасивній стаціонарній рекреації. Він знаходиться безпосередньо в межах с. Велика Круча і володіє значною часткою рекреаційних об'єктів, що не мають відношення до природоохоронної діяльності. Це місцева пивоварня, де влаштовують екскурсії і дегустацію пива, Михайлівська церква і невеличка сільська каплиця, музей українського побуту, об'єкти монументального мистецтва, сувенірні магазини. Крім того, в межах рекреаційного модулю 1 знаходиться кемпінг 3 усіма зручностями для проведення сучасного комфортного відпочинку біля р. Удай [9]. Власники кемпінгу пропонують відпочиваючим широкий набір рекреаційних занять: екскурсії лісом зі збором грибів, ягід, лікарських трав, риболовлю, футбол та волейбол на спеціально облаштованих майданчиках, купально-пляжний відпочинок. Доступ до обладнаного піщаного пляжу мають лише відвідувачі кемпінгу.

Спеціалізація рекреаційного модулю 2 представлена екосплавами по р. Удай (екскурсійнопізнавальні, оздоровчо-спортивні), риболовлею i купально-пляжним відпочинком. Серед зазначених видів спеціалізації в межах рекреаційного модулю 2 наразі не реалізовується пляжний відпочинок. Варто було б тут створити тут піщаний пляж на зразок того, що знаходиться біля кемпінгу в рекреаційному модулі 1. Хоча рекреаційний модуль 2 знаходиться чітко в межах природоохоронної зони, проте за співпраці 3 адміністрацією НПП «Пирятинський» все ж можна знайти місце на правому березі р. Удай в межах рекреаційного модулю 2, де для створення пляжу необхідне буде мінімальне втручання людини: поставити кабінку для переодягання, зробити нешироку піщану смугу на березі річки і розчистити від очерету підходи до води. Урни для сміття можна спочатку спробувати не встановлювати, враховуючи еколого-освітню спрямованість відпочинку в межах природоохоронних територій.

В межах рекреаційного модулю 2 на околицях c. Повстин нижче за течією р. Удай працівниками НПП «Пирятинський» створено три навіси від дощу зі столами та мангалами, а також санітарна зона біля них, зроблені містки до води. Саме тут може бути 
проміжна зупинка для учасників сплавів по р. Удай в межах Приудайського АТРК.

Рекреаційний модуль 2 - це яскравий представник зон рекреації в межах природоохоронних територій навколо річок. Враховуючи необхідність мінімізувати будь-який вплив людини на природу в межах об'єктів і територій природно-заповідного фонду, варто звернути увагу на транспортну доступність русла р. Удай для організації рекреації в межах рекреаційного модулю 2. Так, якщо рекреанти бажають потрапити до останнього на ділянці між с. Повстин і с. Дейманівка, то це видається досить складним, а для декого i неможливим завданням, адже там відсутня дорожня мережа. Таким чином, автомобільна доступність не $\epsilon$ позитивною характеристикою Приудайського АТРК і всіх інших АТРК, що знаходяться в межах природоохоронних територій.

Інша справа - доступність 3 річки. Так, рекреанти прибувають до причалу для човнів, до якого йде автомобільна дорога, а далі сплавляються по річці, що дає їм змогу організувати зупинки по маршруту і пройтись до тих оглядових майданчиків, які не є доступними для під'їзду автомобілем. Тобто, використання безмоторного водного транспорту - це найкращий варіант для отримання високого рівня транспортної доступності до об'єктів стаціонарної рекреації в межах природоохоронних АТРК.

Висновки. У підсумку зазначимо, що Приудайський АТРК володіє значним набором рекреаційних ресурсів, характеризується природоохоронною рекреаційною спеціалізацією, яка майже не потребує кардинального перепланування та обладнання територій. Крім того, неприродоохоронні території проведення рекреації в межах Приудайського АТРК на цей час вже чудово обладнані.

Наразі Приудайський АТРК, хоча в цілому i володіє широким набором рекреаційних об'єктів і територій, є досить маловідомим серед населення України. Враховуючи незначні рекомендації по оптимізації функціональної організації та створивши потужну медіа-рекламу цього двоякого місця відпочинку, де з одного боку - пасивний відпочинок у кемпінгу і пивоварні, а з іншого - активні екосплави по р. Удай, можна за декілька років перетворити Приудайський АТРК на популярний центр рекреації. Крім того, ключовим аспектом функціонального планування територій i акваторій будь-якого АТРК має стати відсутність рукотворних засобів облаштування, що не адаптовані до оточуючого ландшафту і яскравою плямою виділяються на його фоні. Слід поважати територію, яку відвідуємо, і намагатися зберегти їі природний дух та унікальну самобутність. Тому головним питанням при плануванні функціональної організації рекреаційних модулів в межах АТРК має збереження атрактивного природного середовища АТРК в ході організації в його межах місць і засобів відпочинку, гігієни та безпеки.

\section{References:}

1. Bell S. Design for outdoor recreation, London: Spon Press, 2005, 401 p.

2. Brown T. C. Water availability and recreational opportunities. In: Riparian Areas of the Southwestern United States: Hydrology, Ecology, and Management (Ed.: M. B. Baker), New-York: Lewis Publishers, 2003, pp. 299314.

3. Derzhavni budivel'ni normi Ukraïni. Blagoustrij teritorij: DBN B.2.2-5:2011. - K.: Ministry of Regional Development, Construction, and Housing of Ukraine, 2011, 64 p.

4. Ukrainian State Construction Rules. Planning and construction of urban and rural settlements: DBN 360-92**, Ministry of Regional Development and Construction of Ukraine, 2009, $142 \mathrm{p}$.

5. Novikov A.V. Razvitie turistsko-rekreacionnyh zon v celjah gosudarstvenno-chastnogo partnerstva [Development of tourist recreational zones to achieve the state-private partnership], Kazan, 2012 , 216 p. (In Russian).

6. Provisions for recreational activities within the areas and objects of Natural Reserve Fund of Ukraine dated 22.06.2009 N 330. Access mode: http://zakon3.rada.gov.ua/laws/show/z0679-09

7. Vasil'ev Ju. S., Kukushkin V. A. Ispol'zovanie vodoemov i rek v celjah rekreacii [The use of reservoirs and rivers for recreation purposes], Lviv, 1983, 229 p. (In Russian).

8. Official Site of Pyriatynskyi National Natural Park. Access mode: www.npp-p.org.ua.

9. Official Site of JSC "Velyka Krucha". Access mode: www.velykakrucha.com.ua. 